\title{
The Mediating Role of Self-Efficacy in the Relationship between Problem Solving and Hope
}

\author{
Zekeriya ÇAM ${ }^{*}$
}

Faculty of Education, Muş Alparslan University, Muş, Turkey

ORCID: 0000-0002-2965-2390

\section{Mustafa EȘKİSU}

Faculty of Education, Erzincan Binali Yildirım University, Erzincan Turkey

ORCID: 0000-0002-7992-653X

Ferhat KARDAŞ

Faculty of Education, Van Yüzüncü Yıl University, Van, Turkey

ORCID: 0000-0003-3386-3956

\section{Özkan SAATÇİOĞLU}

Faculty of Education, Muş Alparslan University, Muş, Turkey

ORCID: 0000-0001-8131-9619

\section{Sedat GELİBOLU}

Faculty of Education, Muş Alparslan University, Muş, Turkey

ORCID: 0000-0002-9451-7435

Article history

\section{Received:}

22.10.2019

Received in revised form: 19.12.2019

Accepted:

25.12.2019

Key words:

hope; problem solving; selfefficacy.
The current study aims to investigate the relationship among problem solving, hope, and self-efficacy and to test a model for determining the role of self-efficacy in the relationship between problem solving and hope. It adopted convenience sampling and consisted of 494 undergraduate students (369 females; 125 males). The Hope Scale, General Self-Efficacy Scale and Problem Solving Inventory were applied in order to collect the data. Pearson correlation analysis and two-step Structural Equation Modelling were used for data analysis. Findings revealed that while a high level of positive correlation existed among problem solving, self-efficacy and hope, a moderate positive relationship was found between self-efficacy and hope. As a result of Structural Equation Modelling, self-efficacy was found to be significantly predicted by problem solving whereas hope was observed to be significantly predicted by problem-solving and self-efficacy. In addition, mediation analysis demonstrated that the relationship between problem solving and hope emerged through the development of self-efficacy. As a result, this paper exhibited that individuals with developing problem solving ability had also developing self-efficacy, which in turn leads to an increase in hope. Therefore, it may be effective to take into account the components that will improve individuals' problem solving skills and perceptions about themselves while conducting the studies to raise the hope level, which is an important concept of psychological health. 


\section{Introduction}

Hope refers to an individual's planning of ways to achieve the desired goals and his/her motivation to use them (Snyder, Rand, \& Sigmon, 2005; Snyder, 1995). Hope can be considered in three dimensions: the fact that individual has the desired objectives, the capacity of the individual to produce ways to achieve these goals, and individual's motivation to use existing ways to achieve the desired results (Snyder, Rand, \& Sigmon, 2005). The sense of hope allows individuals to be decisive in achieving their goals and to think that there are various ways to achieve their goals (Hefferon \& Boniwell, 2011). According to this conceptualization, at the centre of hope concept is the process of meeting obstacles, planning the ways to overcome them and actively fulfilling these plans (Carr, 2013). Various studies have shown that having high hopes positively correlates with well-being, being healthy, problem solving, social support and psychological adjustment while it negatively correlates with variables such as aggression, depression, suicidal ideations and anxiety (Atik \& Erkan Atik, 2017; Duan, Ho, Bai, \& Tang, 2013; Huen, Ip, Ho, \& Yip, 2015; O’Sullivan, 2011; Oğuztürk, Akça, \& Şahin, 2011; Snyder, Cheavens, \& Michael, 1999; Snyder, Rand, \& Sigmon, 2005; Snyder, 2002; Valle, Huebner, \& Suldo, 2006).

One of the hope-related variables discussed in the literature is problem solving. Problem solving is defined as the process of finding solutions to certain problems (D'Zurilla \& MaydeuOlivares, 1995) and the state of finding new ways to solve a problem by going beyond the simple application of the rules learned through previous experiences (Korkut, 2002). Problem solving is one of the most widely used approaches to the difficulties encountered, traumatic experiences and stressful life events that need to be coped with and it is one of the features that is frequently investigated in this context (Li, Eschenauer, \& Persaud, 2018). Numerous studies indicate problem solving as one of the influential factors in dealing with stressful life events and general psychological adjustment (Heppner, Pretorius, Wei, Lee, \& Wang, 2002) and that there are significant relationships between problem solving styles and psychopathology (Vatan \& Dağ, 2009). Considering the problem solving approach, problem solving process is handled within the framework of problem solving confidence, approach-avoidance and personal control dimensions (Heppner \& Petersen, 1982). On the one hand, the fact that individuals have effective problem solving skills increases their well-being by enabling them to cope with possible problems more easily, but on the other hand, it strengthens not only their beliefs and expectations about coping effectively with the problems they face but also their self-efficacy beliefs. This indirectly enables individuals to have more meaningful goals, to plan ways to achieve these goals and motivates them to achieve their goals. In other words, it can be argued that problem solving indirectly increases individuals' hopes. Thus, self-efficacy is thought to have an indirect effect on the relationship between problem solving and hope.

Albert Bandura defines the concept of self-efficacy as an individual's belief in his or her capacity to perform the actions necessary to cope with various situations or to be effective in the events that control his or her life (Bandura, 1989). Self-efficacy has four sources of information: mastery experiences, vicarious experience, verbal persuasion, and physiological and emotional states (Bandura, 1997). Accordingly, when an individual achieves something and becomes an expert in that business, observes the conditions and situations in which other people have succeeded, and if this person is encouraged and persuaded by certain people in that he or she will be successful, a positive feeling related to the aims is developed, which all make up the main sources strengthening the self-efficacy belief. In this context, self-efficacy belief directly or indirectly affects the behaviours of people, their endeavours, their level of endurance against obstacles and failures, their resistance to difficulties, and the stress and depression they face while dealing with environmental demands (Kandemir, 2015). 


\section{The Role of Self-Efficacy in the Relationship between Hope and Problem Solving}

Several similarities and differences exist among hope, self-efficacy, and problemsolving theories. In this sense, it is vital to examine the relationship among the related variables within the framework of a structural model. Various studies have revealed the relationships among hope, problem solving, and self-efficacy and proposed different models for these relationships. The literature presents the relationship between problem solving and self-efficacy belief and different types of self-efficacy (Erözkan, 2014; Heppner et al., 2002). A significant relationship was found to exist between problem solving and hope as well as hopelessness. Accordingly, a significant relationship was found between problem solving and hope, and it was determined that weak problem-solving skill was a variable predicting suicidal ideation and low problem-solving skills predicted suicidal ideations through hopelessness (Abdollahi, Talib, Yaacob, \& Ismail, 2016; Snyder, Cheavens, \& Michael, 1999). This reveals that low level of problem solving skills is one of the factors that increases the feelings of hopelessness in individuals and problem solving is a variable associated with hope. Many studies have exhibited the significant relationship between self-efficacy and hope. Thus, the concept of self-efficacy is considered to be related to the ways to achieve the goal and motivation, which are components of hope (Snyder, Rand, \& Sigmon, 2005). This reveals that self-efficacy and problem-solving are strong predictors of hope (Atik \& Erkan Atik, 2017). Based on all these relationships, a model is suggested that strong problem solving skills increases individuals' self-efficacy beliefs and this indirectly increases their hopes. Figure 1 presents the proposed model.

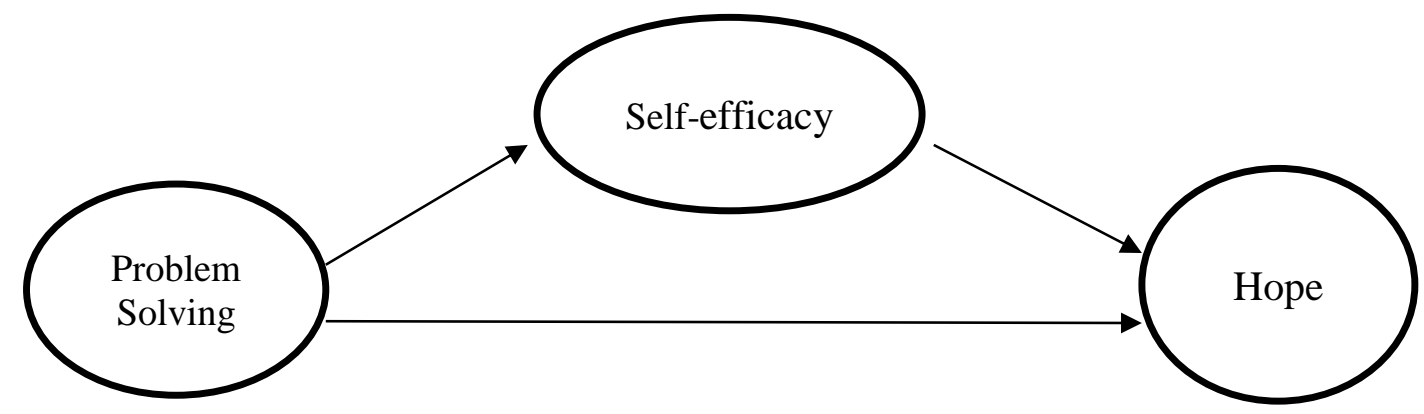

Figure 1. Tested hypothetical model.

Although literature presents many studies examining the relationship among hope, selfefficacy, and problem solving, no studies have been found to determine the direct and indirect effects between these variables. This indicates that there is a need to put forward the relationship mechanism and to determine the mediating effects, if any. On the other hand, the concept of hope is often considered as a predictor variable in the literature. In addition, self-efficacy is stated to be a resource that increases problem solving skills of individuals and the increasing self-efficacy strengthens problem solving skills. In this study, it is proposed that hope increases depending on successful problem solving experiences and that problem solving is one of the sources that increases self-efficacy. To that end the hypotheses of the research are as follows;

(1) Problem solving significantly predicts self-efficacy.

(2) Problem solving significantly predicts hope.

(3) Self-efficacy significantly predicts hope.

(4) Problem solving predicts hope through self-efficacy. 


\section{Method}

\section{Participants}

The participants of the current study consisted of 494 volunteer undergraduate students Turkey. Of the participants, 369 (74.7\%) were female and $125(25.3 \%)$ were male. The grade levels of them were; 145 (29.4\%) freshmen, 137 (27.7\%) sophomores, 174 (35.2\%) juniors and $38(7.7 \%)$ seniors. The ages of the students ranged from 17 to 30 years and the mean age was 20.07 ( $\mathrm{SD}=1.79$ ) years. Before administering the scales, a consent form was given to the participants.

\section{Measures}

\section{The Hope Scale}

The Hope Scale (Snyder et al., 1991) which was developed by Snyder et al. and adapted to Turkish culture by Akman and Korkut (1993) was used in order to assess hope levels of the participants. The scale consists of two sub-dimensions; pathways and agency, and each dimension has four items. Remaining four items are fillers and they are not included in the scoring. In this way the scale consists of 12 items in total. In the Turkish form items are responded to on a 4-point scale (1: strongly disagree, to 4: strongly agree). The scores can be obtained from the scale ranged 8 to 32 . The higher scores indicate the high level of hope on certain situations. The internal consistency score for the original version was reported as .75 . The internal consistency scores for agency sub-dimension was found to be .71 and .67 for pathways. Test-retest reliability coefficients were found .85 for 3 weeks interval, .73 for 8 weeks interval and .76 for 10 weeks interval respectively and they are all significant in $p<.001$ level (Snyder et al., 1991). The Turkish version of the scale has internal consistency coefficient as $.65(\mathrm{p}<.001)$ and test-retest reliability coefficients as .66 $(\mathrm{p}<.001)$ for 4 weeks interval. In the current study we found the internal consistency coefficient as .73 and we have done a confirmatory factor analysis (CFA) on our sample in order to confirm the construct. In our CFA two factors construct was validated and had adequate fit indices $\left[\chi^{2}=59.448, \chi 2 / \mathrm{df}=3.13\right.$, RMSEA $=.066, \mathrm{SRMR}=.064, \mathrm{GFI}=.98, \mathrm{NFI}=.94, \mathrm{CFI}=.96]$.

\section{General Self-Efficacy Scale:}

General Self-Efficacy Scale which was developed by Sherer et al. (1982) was used to determine self-efficacy. In the original form there are two factors construct which are general self-efficacy (Cronbach's alpha $=.86$ ) and social self-efficacy (Cronbach's alpha $=.71$ ). These two factors consist of 23 items in total. The general self-efficacy sub-scale was recommended to be used and this sub-scale was adapted to Turkish culture by Y1ldırım and İlhan (2010). Items were rated on a 5 point scale. The scores obtained from the scale range from 17 to 85 and higher scores indicate greater self-efficacy beliefs on certain situations. Internal consistency coefficient was reported as .80 ( $<<.001)$ and test-retest reliability coefficient as .69 ( $<<.0001)$ for 3 weeks interval. In the current study we found internal consistency coefficient as .86. Also we made a CFA and saw that 3 factors construct has been validated and we obtained acceptable fit indices $[\chi 2=196.995, \chi 2 / \mathrm{df}=1.70, \mathrm{RMSEA}=.038, \mathrm{SRMR}=.054, \mathrm{GFI}=.98, \mathrm{NFI}=.96$, $\mathrm{CFI}=.98]$. 


\section{Problem Solving Inventory:}

Problem Solving Inventory (PSI) was also used for assessing students' problem solving beliefs and behaviours in the study. PSI was developed by Heppner and Petersen (1982) and adapted to Turkish culture by Şahin, Şahin and Heppner (1993). The original scale has three factors which are; problem solving confidence, approach-avoidance style, and personal control. Total score is calculated by summing up these three sub-dimensions. It is filled on a 6 points scale and minimum score obtained from the scale would be 32 and maximum would be 192 . Higher scores mean that participants perceive themselves inefficient in problem solving skills. The internal consistency coefficient for original form ranged to .75 to .90 . Unlike the original form Turkish version has six factors structure. These six factors are: Impulsivity $(\alpha=0.78)$, Reflective ( $\alpha=.76)$, Avoidant ( $\alpha=.74)$, Monitoring ( $\alpha=.69)$, Problem-solving confidence $(\alpha=.64)$ and Planfulness $(\alpha=.59)$. In the current study we used Turkish form of the PSI and calculated internal consistency coefficient as .90 . According to the results of CFA done in this study; fit indices of the six-factor model were found to be good $[\chi 2=1327.94, \chi 2 / \mathrm{df}=2.96$, RMSEA $=$ $.061, \mathrm{SRMR}=.060, \mathrm{GFI}=.84, \mathrm{NFI}=.95, \mathrm{CFI}=.96]$.

\section{Data Analyses}

We carried out a SEM path analysis to examine the relationships among variables as well as the role of self-efficacy in the relationship between problem solving and hope. We used skewness and kurtosis scores to examine normality and multivariate kurtosis score to examine multivariate non-normality and determined outliers using Mahalanobis distance (Kline, 2011). After assessing the measurement model, we tested our structural model using problem solving in predicting self-efficacy which in turn predicted hope (see Figure 2). We used conventional model fit statistics and their cut-off points to assess goodness-of-fit (Hu \& Bentler, 1999; Schermelleh-Engel, Moosbrugger, \& Müller, 2003). We used bootstrapping percentile confidence interval methods to test the significance of the indirect effect of the problem solving on hope through self-efficacy.

\section{Results}

\section{Preliminary Analyses}

In preliminary analyses, we examined the normality, multivariate normality and internal reliability of variables and we performed Pearson product-moment correlation analysis. Preliminary analyses showed that skewness and kurtosis scores ranged from -.742 to .162 and multivariate kurtosis value is 3.074 (critical ratio is 2.020). Skewness and kurtosis scores between -1 and 1 verify the univariate normality (Tabachnick \& Fidell, 2013) and critical ratio of multivariate kurtosis score $<5$, Byrne (2006) demonstrates that multivariate normality is not violated. Pearson product-moment correlation analysis showed that problem solving had a positive correlation with self-efficacy $(r=.782 ; \mathrm{p}<.01)$ and hope $(r=.619 ; \mathrm{p}<.01)$. Moreover, self-efficacy was positively correlated with hope $(\mathrm{r}=.595 ; \mathrm{p}<.01)$. Table 1 provides descriptive statistics, internal reliability coefficients and correlation matrix of variables. 
Table 1. Correlation matrix and descriptive statistics.

Problem solving Self-efficacy

Hope

\begin{tabular}{llll}
\hline Problem solving & -- & & \\
Self-efficacy & $.782^{* *}$ & -- & - \\
Hope & $.619^{* *}$ & $.595^{* *}$ & 26.13 \\
\hline Mean & 136.42 & 61.94 & 2.95 \\
SD & 18.81 & 9.21 & .73 \\
$\alpha$ & .90 & .86 & \\
\hline
\end{tabular}

Note: $N=494 ; \alpha=$ Internal reliability coefficients in this study; $* * p<.01$.

\section{Measurement Model}

In analysing data, we considered two-step SEM procedure (Anderson \& Gerbing, 1988): Firstly we carried out a confirmatory factor analysis for the measurement model and then we performed a structural model to test our hypothesis. A two-step SEM procedure was adopted in the present study because of its advantages against the one-step approach (Anderson \& Gerbing, 1988) and its widespread use (Kline, 2011).

We used impulsive, reflective, avoidant, monitoring, problem-solving confidence and planfulness, the subscales of PSI as the observed indicators of the latent variable of problem solving. Likewise, HS's subscales, pathway and agency were used to determine the latent structure of hope and SEC's subscales, start-up, perseverance and persistence, were used as the observed indicators of self-efficacy.

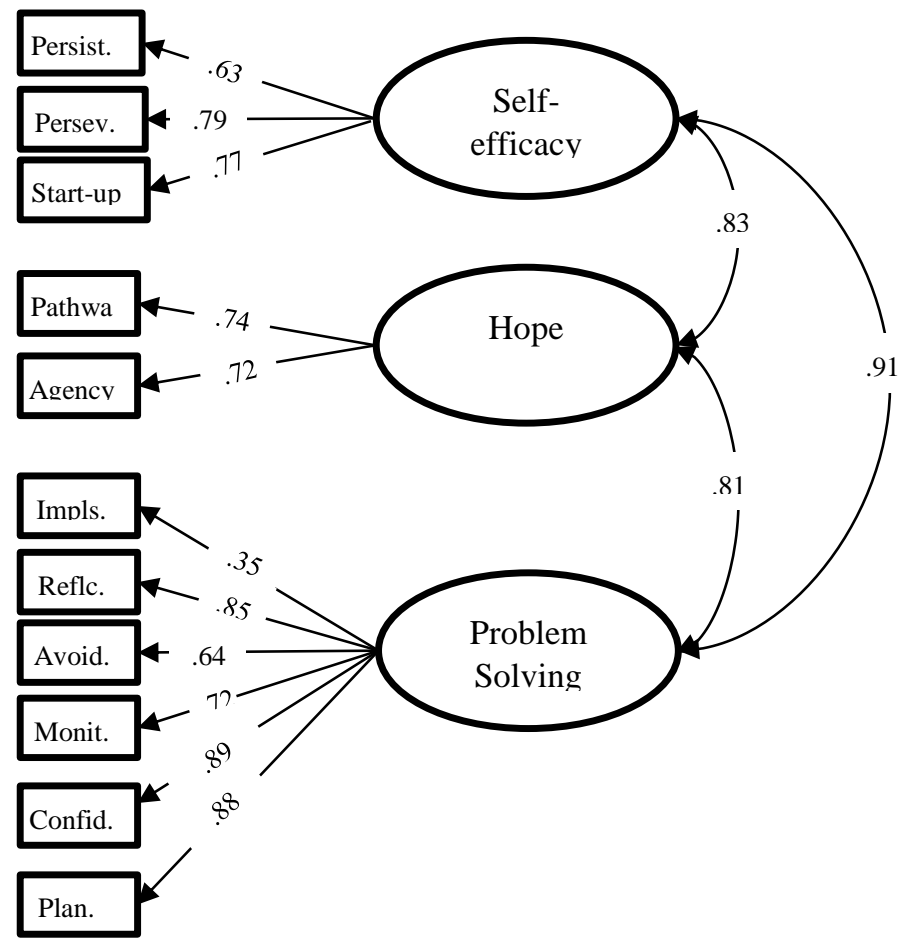

Figure 1. Measurement model*.

* Impls: Impulsivity, Reflc: Reflective, Avoid: Avoidant, Monit: Monitoring, Confid: Problemsolving confidence, Plan: Planfulness. All coefficients are significant at $\mathrm{p}<.001$ level. 
The measurement model provided good model fit $(\chi 2=188.374, \mathrm{df}=39, \chi 2 / \mathrm{df}=4.83, \mathrm{p}=.014$, RMSEA $=.088$ [90\% confidence interval $(\mathrm{CI})=.076-.101]$, GFI $=.94, \mathrm{CFI}=.95, \mathrm{NFI}=.94$, IFI=.95). Each observed variable significantly loaded on its respective latent variable. Consequently, it shows that observed variables may measure their latent variables. Intercorrelations among the latent variables were statistically significant at $\mathrm{p}<.001$ level (Figure 2).

\section{Structural Model}

We tested a structural model that includes a relationship between problem solving and hope through self-efficacy. For this purpose, the specified model provided a good model fit and resulted in well fit to data $\chi 2=188.374, \mathrm{df}=39, \chi 2 / \mathrm{df}=4.83, \mathrm{p}<.001$, RMSEA $=.088[90 \%$ confidence interval $(\mathrm{CI})=.076-.101]$, GFI=.94, CFI=.95, NFI=.94, IFI=.95. Confirming our hypothesis, standardized regression coefficients showed that problem solving was the positive predictor of self-efficacy $(\beta=.91, \mathrm{SE}=.073, \mathrm{p}<.001)$ and self-efficacy significantly predicted hope $(\beta=.51, \mathrm{SE}=.047, \mathrm{p}<.01)$. Moreover, hope was positively predicted by problem solving $(\beta=.36, \mathrm{SE}=.067, \mathrm{p}<.05)$.

\section{Testing the Indirect Effect: The Role Self-Efficacy}

We used a bootstrap procedure to examine the significance of the indirect effect of the problem solving on hope through self-efficacy. Although Baron and Kenny's (Baron \& Kenny, 1986) model is widely used to determine mediation there are some issues with performing it in analysing the indirect effects. Firstly, this model requires the significant path from dependent variable $(\mathrm{X})$ to independent variable $(\mathrm{Y})$, but some researchers showed that mediation might work out even the absence of the initial significant path from X to Y (Hayes, 2018; Pardo \& Román, 2013). Secondly, this analysis does not tell anything about the significance of the mediation effect. Moreover, indirect effect (the product of the path from $\mathrm{X}$ to mediator variable (M) and the path from M to Y) generally does not has normal distribution (Cheung \& Lau, 2008). Thus, examining the significance of mediation by performing the Sobel test or similar methods that assume normal distribution may not be suitable to test the significance of mediation (MacKinnon, 2008). Moreover Hayes (2018) stated that using the term of "partial mediation" and "complete mediation" has some misleading effects at statistical and philosophical levels.

However, many researchers suggested using the bootstrap method to define the confidence interval of mediation effect, because it does not depend on normal distribution that makes it more accurate in the estimation of standard error of indirect effect (Hayes, 2018; MacKinnon, 2008; Shrout \& Bolger, 2002). On the other hand, SEM has the advantage of controlling measurement error in estimating direct and indirect effects. Cheung and Lau's simulation study also showed that bootstrap percentile method provides a more accurate confidence interval in testing the significance of indirect effect (Cheung \& Lau, 2008). 
Table 2. Bootstrap analyses of the statistical significance of the indirect effect and the direct effect of the problem solving on hope

\begin{tabular}{|c|c|c|c|c|c|}
\hline \multirow[b]{2}{*}{ Path } & \multirow[t]{2}{*}{$\beta$ (Standardized effect) } & \multirow[t]{2}{*}{ SE } & \multicolumn{2}{|c|}{$95 \%$ confidence interval } & \multirow[t]{2}{*}{$\mathrm{p}$} \\
\hline & & & Lower & Upper & \\
\hline PS $>>$ Hope $^{a}$ & .355 & .192 & -.061 & .692 & .089 \\
\hline $\mathrm{PS} \gg \mathrm{SE} \gg \mathrm{Hope}^{\mathrm{b}}$ & .458 & .178 & .152 & .862 & .006 \\
\hline
\end{tabular}

In bootstrap analyses, in the event that zero does not fall down between the upper and lower 95\% CI, the indirect effect is statistically significant at .05 level. The findings from 5000 bootstrap sample indicated that $95 \%$ CI for the indirect effect of problem solving did not include zero, meaning that this indirect effect, problem solving to hope through self-efficacy, is statistically significant. On the other hand, 95\% CI for the direct effect of problem solving includes zero, showing that this direct effect, problem solving to hope, is not statistically significant (Table 3). Consequently, these findings indicated that problem solving has a significant indirect positive effect on hope through self-efficacy. In other words, students with high problem solving skill were more likely to have higher rate of self-efficacy, which, in turn, had positive predictive effect on hope (Figure 3).

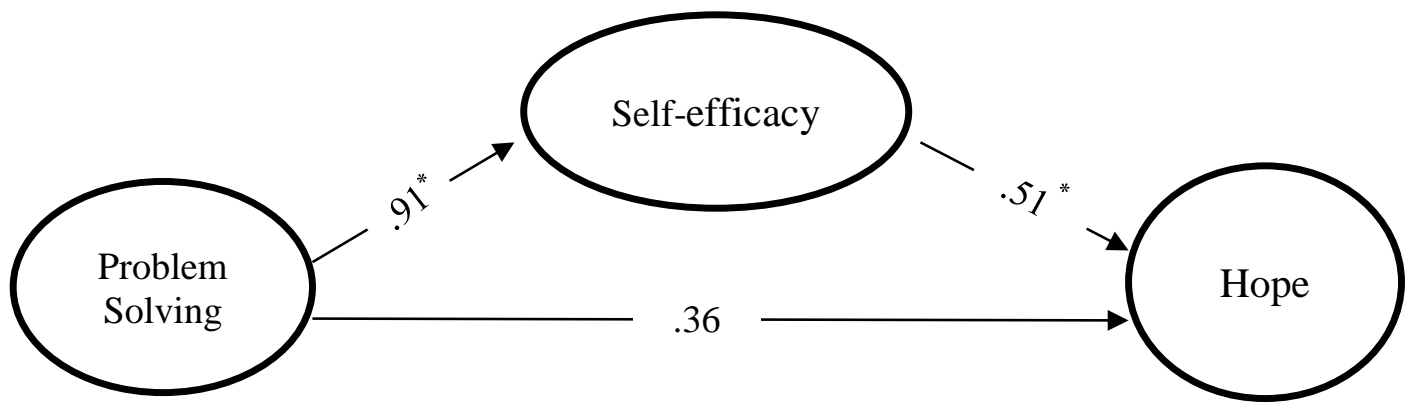

Figure 3. Structural model demonstrating standardized regression confidents between variables. $*=p<.001$.

\section{Discussion and Conclusion}

The current study examined the structural relationships among problem solving, selfefficacy and hope. It revealed that there were positive relationships between all variables in the tested structural model and that problem-solving was associated with hope through selfefficacy. Based on the study results, it can be said that individuals who have high problem solving skills perceive themselves as more adequate and think more hopefully in this way. Researchers advocated that problem-solving capacity was regarded as one of the important features of being human by psychologists and philosophers throughout history because the ability to solve social or other problems makes significant contributions to the qualifications, competencies and psychological well-being of people. More specifically, the ability to solve problems encountered in daily life is an important feature which is related to the personal and social functions of individuals (Nezu, 2004).

As Snyder states in his hope theory, one of the components of hope is purposeful thinking. This kind of thinking is essentially similar to problem solving. Therefore, hope and problem solving 
are considered as related features. Specifically, the agency dimension of hope is listed among the characteristics of individuals who solve problems. A study conducted with high school students exhibited a positive and strong relationship among hope, academic self-efficacy and problem solving. The concept of self-efficacy is related to the agency dimension of hopeful thinking. In addition, hope and self-efficacy concepts are listed among the determinants of an individual's behaviour (Atik \& Erkan Atik, 2017; Witty, Heppner, Bernard, \& Thoreson, 2001). Being one of the positive psychological structures, hope is associated with self-efficacy and problem solving as well as psychological characteristics such as resilience. When people perceive themselves as competent in a particular area (self-efficacy), they persevere in achieving their goals and look for ways to achieve their goals (hope). When they encounter any problems in this process, they can solve these effectively (problem solving) (Luthans, Youssef, \& Rawski, 2011).

People with high problem solving and self-efficacy capacity also exhibit resilience. Individuals with these characteristics are more perseverant in the face of problems they experience in daily life and can bounce back from difficulties (bounce back effect). All these help the person think optimistically (Luthans et al., 2011). If the individual has a low level of self-efficacy and if his/her effective problem-solving skills are not developed, this situation leads to thoughts of chronic depression (dysthymia) and hopelessness. Eventually, these thoughts trigger suicidal ideations (Teo, Suárez, \& Oei, 2018) because problem solving is often associated with mental health. Also, low self-efficacy and individual's belief that behaviours will result in negative outcomes lead to decreased self-esteem, difficulties in decision-making, and the occurrence of major depressive disorders (Teo et al., 2018).

Hopelessness, the opposite concept of hope, is commonly observed in people who have low problem solving skills. However, people who have high problem solving skills exhibit better coping skills in the face of stressful life events they go through in life. Hence it is stated that people who have high problem solving skills think more hopefully (Heppner \& Lee, 2002; Nezu, 2004). Although problem solving depends on the hopelessness levels of individuals, there is also a relationship between problem solving and suicidal thoughts. In particular, problem solving has a mediating effect in the relationship between hopelessness and suicidal ideation. Therefore, problem solving is an important factor that affects hopeful thinking and sense of hope (Cheng, 2001). This instantiates the importance of the relationship among problem solving, self-efficacy and hopeful thinking in terms of preventive mental health.

Shortcomings in problem solving skills cause individuals to experience the stressful situations more intensively and thusly they experience the long-term negative effects of stress more. The long-term continuation of this negative situation means that people experience more depressive emotions such as helplessness and hopelessness (Cheng, 2001). As a result, it is vital to help individuals gain problem solving skills so as to develop hopeful thinking and self-efficacy. Individuals who are faced with problems gradually find the opportunity to improve their selfefficacy by solving increasingly complex problems. In this way, individuals' self-confidence, who overcome the problems, will be developed (Shapiro \& Watson, 2000). Considering the literature, Problem Solving Therapy primarily focused on pathology-oriented issues (negative emotions). However, this approach has become one of the intervention methods of positive psychology. Problem Solving Therapy is considered to be effective in developing positive emotions such as hope and optimism (Nezu, 2004).

Within the life periods, the importance of positive emotions such as hope at old ages is becoming more and more important. In this context, intense positive emotions at an old age 
protect people from the risk of immediate death as well as depressive symptoms. In this sense, enjoyment in life and hope have a function to prevent both potential problems of individuals in interpersonal relationships and the emergence of depressive symptoms. It was found in a study conducted on the elderly that the decrease in problem solving skills caused an increase in depressive emotions (Paterson, Yeung, \& Thornton, 2016). That's why, studies, particularly longitudinal research, examining the relationships among hope, self-efficacy and problem solving skills should be conducted on individuals in different developmental periods.

Considering the findings and literature, it may be useful to implement intervention programs to develop hope which is one of the positive emotions. Adding problem solving and self-efficacy issues to the content of intervention programs may be important in gaining hopeful thinking. Literature presents a limited number of group interventions that were prepared and developed to improve hope. Conducting psycho-educational studies based on group intervention that will be developed within the context of hope theory will contribute to the literature.

\section{References}

Abdollahi, A., Talib, M. A., Yaacob, S. N., \& Ismail, Z. (2016). Problem-solving skills and suicidal ideation among malaysian college students: the mediating role of hopelessness. Academic Psychiatry, 40(2), 261-267. https://doi.org/10.1007/s40596-015-0383-0

Anderson, J. C., \& Gerbing, D. W. (1988). Structural equation modeling in practice: A review and recommended two-step approach. Psychological Bulletin, 103(3), 411-423.

Atik, G., \& Erkan Atik, Z. (2017). Predicting hope levels of high school students: The role of academic self-efficacy and problem solving. Education and Science, 42(190), 157-169. https://doi.org/10.15390/EB.2017.5348

Bandura, A. (1997). Self-efficacy: The exercise of control. New York: Freeman.

Bandura, Albert. (1989). Human agency in social cognitive theory. American Psychologist, 44(9), 1175-1184. https://doi.org/10.1037/0003-066X.44.9.1175

Baron, R. M. \& Kenny, D. A. (1986). Moderator-mediator variables distinction in social psychological research: Conceptual, strategic, and statistical considerations. Journal of Personality and Social Psychology, 51(6), 1173-1182.

Byrne, B. M. (2016). Structural equation modeling with AMOS: Basic concepts, applications, and programming. Routledge.

Carr, A. (2013). Positive psychology: The science of happiness and human strengths. London: Routledge.

Cheng, S. K. (2001). Life stress, problem solving, perfectionism, and depressive symptoms in Chinese. Cognitive Therapy and Research, 25(3), 303-310. https://doi.org/https://doi.org/10.1023/A:1010788513083

Cheung, G. W., \& Lau, R. S. (2008). Testing mediation and suppression effects of latent variables. Organizational Research Methods, 11(2), 296-325. https://doi.org/10.1177/1094428107300343

D'Zurilla, T. J., \& Maydeu-Olivares, A. (1995). Conceptual and methodological issues in social problem-solving assessment. Behavior Therapy, 26(3), 409-432. https://doi.org/10.1016/S0005-7894(05)80091-7

Duan, W., Ho, S. M. Y., Bai, Y., \& Tang, X. (2013). Psychometric evaluation of the Chinese virtues questionnaire. Research on Social Work Practice, 23(3), 336-345. https://doi.org/10.1177/1049731513477214

Erözkan, A. (2014). Analysis of social problem solving and social self-efficacy in prospective teachers. Educational Sciences: Theory \& Practice, 14(2), 447-455. https://doi.org/10.12738/estp.2014.2.2014 
Hayes, A. F. (2018). Introduction to mediation, moderation, and conditional process analysis: A regression-based approach. New York: Guliford.

Hefferon, K., Boniwell, I. (2011). Positive psychology: Theory, research and applications. New York: McGraw Hill.

Heppner, P. P., \& Lee, D. (2002). Problem-solving appraisal and psychological adjustment. In S. J. Snyder, C. R., \& Lopez (Ed.), Handbook of positive psychology (pp. 288-298). Oxford University Press.

Heppner, P. P., \& Petersen, C. H. (1982). The development and implications of a personal problem-solving inventory. Journal of Counseling Psychology, 29(1), 66-75. https://doi.org/10.1037/0022-0167.29.1.66

Heppner, P. P., Pretorius, T. B., Wei, M., Lee, D., \& Wang, Y.-W. (2002). Examining the generalizability of problem-solving appraisal in Black South Africans. Journal of Counseling Psychology, 49(4), 484-498. https://doi.org/10.1037/0022-0167.49.4.484

Hu, L. T., \& Bentler, P. M. (1999). Cutoff criteria for fit indexes in covariance structure analysis: Conventional criteria versus new alternatives. Structural Equation Modeling: A Multidisciplinary Journal, 6(1), 1-55.

Huen, J. M. Y., Ip, B. Y. T., Ho, S. M. Y., \& Yip, P. S. F. (2015). Hope and hopelessness: the role of hope in buffering the impact of hopelessness on suicidal ideation. Plos One, 10(6), e0130073. https://doi.org/10.1371/journal.pone.0130073

Jöreskog, K., \& Sörbom, D. (1993). LISREL 8: Structural equation modeling with the SIMPLIS command language. Scientific Software.

Kandemir, M. (2015). Öz yeterlik [Self efficacy]. In Ş. Ergüner Tekinalp, B., Işık Terzi (Ed.), Ĕgitimde pozitif psikoloji uygulamalarl [Positive psychology implications in education] (pp. 39-69). Ankara: Pegem Akademi.

Kline, R. B. (2011). Principles and practice of structural equation modeling (Third edition). New York: Guliford.

Korkut, F. (2002). Lise öğrencilerinin problem çözme becerileri [Problem solving skills of high school students]. Hacettepe Üniversitesi Eğitim Fakültesi Dergisi [Hacettepe University Journal of Faculty of Education], 22, 177-184.

Li, M., Eschenauer, R., \& Persaud, V. (2018). Between avoidance and problem solving: resilience, self-efficacy, and social support seeking. Journal of Counseling \& Development, 96(2), 132-143. https://doi.org/10.1002/jcad.12187

Luthans, F., Youssef, C. M., \& Rawski, S. L. (2011). A tale of two paradigms: the impact of psychological capital and reinforcing feedback on problem solving and innovation. Journal of Organizational Behavior Management, 31(4), 333-350. https://doi.org/10.1080/01608061.2011.619421

MacKinnon, D. (2008). Introduction to statistical mediation analysis. Routledge.

Marsh, H. W., \& Hocevar, D. (1985). Application of confirmatory factor analysis to the study of self-concept: First- and higher order factor models and their invariance across groups. Psychological Bulletin, 97(3), 562-582. https://doi.org/10.1037/0033-2909.97.3.562

Nezu, A. M. (2004). Problem solving and behavior therapy revisited. Behaviour Therapy, 35, 1-33. https://doi.org/https://doi.org/10.1016/S0005-7894(04)80002-9

O'Sullivan, G. (2011). The relationship between hope, eustress, self-efficacy, and life satisfaction among undergraduates. Social Indicators Research, 101(1), 155-172. https://doi.org/10.1007/s11205-010-9662-z

Oğuztürk, Ö., Akça, F., Şahin, G. (2011). Üniversite öğrencilerinde umutsuzluk düzeyi ile problem çözme becerileri arasındaki ilişkinin bazı değişkenler üzerinden incelenmesi [Investigation of relationship between hopeless level and problem solving skills in the aspects of some variables]. Klinik Psikiyatri [Turkish Journal of Clinical Psychiatry], 14, 85-93. 
Pardo, A., \& Román, M. (2013). Reflections on the Baron and Kenny model of statistical mediation. Anales de Psicología, 29(2), 614-623. https://doi.org/10.6018/analesps.29.2.139241

Paterson, T. S. E., Yeung, S. E., \& Thornton, W. L. (2016). Positive affect predicts everyday problem-solving ability in older adults. Aging \& Mental Health, 20(8), 871-879. https://doi.org/10.1080/13607863.2015.1043619

Schermelleh-Engel, K., Moosbrugger, H., \& Müller, H. (2003). Evaluating the fit of structural equation models: tests of significance and descriptive goodness-of-fit measures. Methods of Psychological Research Online, 8(2), 23-74.

Schumacker, R. E. \& Lomax, R. G. (2004). A beginner's guide to structural equation modeling. Lawrence Erlbaum.

Shapiro, D. L., \& Watson, A. (2000). Using the theory of planned behavior to induce problem solving in schools. Negotiation Journal, 16(2), 183-190. https://doi.org/10.1111/j.1571-9979.2000.tb00212.x

Shrout, P. E., \& Bolger, N. (2002). Mediation in experimental and nonexperimental studies: New procedures and recommendations. Psychological Methods, 7, 422-445.

Snyder, C. R., Cheavens, J., Michael, S. T. (1999). Hoping. In C. R. Snyder (Ed.), Coping: The psychology of what works (pp. 205-231). Oxford: Oxford University Press.

Snyder, C. R., Rand, K. L., \& Sigmon, D. R. (2005). Hope theory: A member of the positive psychology family. In Handbook of positive psychology (pp. 257-276). New York: Oxford University Press.

Snyder, C. R. (1995). Conceptualizing, measuring, and nurturing hope. Journal of Counseling \& Development, 73(3), 355-360. https://doi.org/10.1002/j.1556-6676.1995.tb01764.x

Snyder, C. R. (2002). Hope theory: Rainbows in the mind. Psychological Inquiry, 13(4), 249275. https://doi.org/10.1207/S15327965PLI1304_01

Snyder, C. R., Harris, C., Anderson, J. R., Holleran, S. A., Irving, L. M., Sigmon, S. T., ... Harney, P. (1991). The will and the ways: Development and validation of an individualdifferences measure of hope. Journal of Personality and Social Psychology, 60(4), 570585. https://doi.org/10.1037/0022-3514.60.4.570

Tabachnick, B. G. \& Fidell, L. S. (2013). Using multivariate statistics (Sixth edition). Boston: Pearson.

Teo, D. C. H., Suárez, L., \& Oei, T. P. S. (2018). Psychometric properties of the problem solving inventory in a Singapore young male adult sample. Current Psychology. https://doi.org/10.1007/s12144-018-0073-7

Valle, M. F., Huebner, E. S., \& Suldo, S. M. (2006). An analysis of hope as a psychological strength. Journal of School Psychology, 44(5), 393-406. https://doi.org/10.1016/j.jsp.2006.03.005

Vatan, S., Dağ, İ. (2009). Problem çözme, umutsuzluk, çaresizlik ve talihsizlik MMPI-2 ile ölçülen psikopatolojinin yordayıcıları olabilir mi [Problem solving style, hopelessness, helplessness and haplessness as the predictors of psychopathology assessed by MMPI2]. Anadolu Psikiyatri Dergisi [Anatolian Journal of Psychiatry], 10, 187-197.

Witty, T. E., Heppner, P. E., Bernard, C. B., \& Thoreson, R. W. (2001). Problem-solving appraisal and psychological adjustment of persons with chronic low-back pain. Journal of Clinical Psychology in Medical Settings, 8(3), 149-160. https://doi.org/https://doi.org/10.1023/A:1011361418436

Yıldırım, F., İlhan, İ. Ö. (2010). Genel özyeterlilik ölçeği Türkçe formunun geçerlilik ve güvenilirlik çalışması [The validity and reliability of the general self efficacy scaleTurkish form]. Türk Psikiyatri Dergisi [Turkish Journal of Psychiatry], 21(4), 301-308. 